\title{
Effect of Time of Pruning on Fruit Production and Berry Quality of Grapes (Vitis vinifera) under Bankura Condition of West Bengal
}

\author{
Ranjit Pal ${ }^{*}$ and S.N. Ghosh ${ }^{2}$ \\ ${ }^{1}$ Department of Fruit Science, Rani Lakshmi Bai Central Agricultural University, Jhansi, \\ Utter Pradesh Pin-284003, India \\ ${ }^{2}$ Department of Fruits and Orchard Management, Faculty of Horticulture, Bidhan Chandra \\ Krishi Viswavidyalaya, Mohanpur, Nadia, West Bengal, Pin-741252, India \\ *Corresponding author
}

\section{A B S T R A C T}

In India, viticulture is one of the most important horticultural industries in views of its area, production, productivity, value addition and employment creation in both rural and urban areas. The grape in West Bengal is now a new fruit crop for utilizing the up and medium fallow lands in western part of the state. In this part, the soil is red and laterite and

\section{Keywords}

Grape, Arka

Trishna, Pruning, Yield, Quality

\section{Article Info}

Accepted: 15 September 2018 Available Online: 10 October 2018 acidic in nature and this area received very low rainfall and experience a long dry spell during month of January to May. In such climatic condition pruning is often considered as emergency practice. Correct time and proper pruning very important for productive and healthy over the life of grapevine. As there was no attempt was made to find out proper time of pruning on grape vines under this climatic condition. The aim of this research was to standardize the proper time of pruning on cultivar Arka Trishna under this condition. The investigation was therefore under taken in this direction. The study was conducted at Taldangra in Bankura district of West Bengal (India) during 2012 and 2014. The vine was pruned on four different dates i.e. $20^{\text {th }}$ January, $30^{\text {th }}$ January, $10^{\text {th }}$ February and $20^{\text {th }}$ February. The experiment was laid out in a Randomized Block Design with six replications. The vines were trained on ' $\mathrm{Y}$ '-trellis system. The results indicated that maximum yield and yield attributes character per vine was recorded when vines were pruned on $30^{\text {th }}$ January. The berry quality was increased when vines were pruned on $20^{\text {th }}$ February. On the basis of present findings, it can be concluded that $30^{\text {th }}$ January appeared to be the appropriate time for pruning the vines under Bankura conditions with regard to yield attributes and quality.

\section{Introduction}

In India, viticulture is one of the most important horticultural industries in views of its area, production, productivity, value addition and employment creation in both rural and urban areas. Traditionally, grapes are important fruit crops of temperate region of the world, but in India, grape is grown under temperate, subtropical and tropical climatic condition (Chadha, 2008). The area under grape cultivation is increasing day by day in India. The grape in West Bengal is now a new fruit crop for utilizing the up and medium 
fallow lands in western part of the state. In this part, the soil is red and laterite and acidic in nature and this area received very low rainfall and experience a long dry spell during month of January to May. In grape cultivation, the most important and expensive cultural operation is pruning and it is plays an important role in grape which affects yield and quality of grapes (Chadha and Shikhamany, 1999). In such climatic condition pruning is often considered as emergency practices. Correct time and proper pruning very important for productive and healthy over the life of grapevine. As there was no attempt was made to find out proper time of pruning on Arka Trishna cultivar of grapes under this climatic condition. The cultivar Arka Trishna is hybrid between Bangalore Blue x Convent Large Black. It is very high yield potential, less susceptible to insects and diseases (Radha and Mathew, 2007). It is possible to take two crops in a year in Bangalore condition but in West Bengal condition only one crop is possible. The aim of this research was to standardize the proper time of pruning on cultivar Arka Trishna under this climatic condition.

\section{Materials and Methods}

The investigation was carried out at the Horticultural Research and Development Farm, Govt. of West Bengal, Taldandra district Bankura during 2012-2014.

The site is situated at $23^{\circ} 01^{\prime} 60^{\prime}$ " $\mathrm{N}$ latitude and $87^{\circ} 06^{\prime} 00$ ' $\mathrm{E}$ longitude with an altitude of $88.0 \mathrm{~m}$ above mean sea level. The site is subtropical with little rainfall during summer. The average precipitation (June to October) in the area about $1100 \mathrm{~mm}$. The maximum and minimum temperature during summer months varies between $40^{\circ} \mathrm{C}$ and $24^{\circ} \mathrm{C}$ respectively while during winter it ranges between $25.5^{\circ} \mathrm{C}$ and $11.2^{\circ} \mathrm{C}$. The soil of the orchard was laterite having pH 6.5, Organic Carbon $0.55 \%$.
Available (natural) soil content of nitrogen $(\mathrm{N})$, phosphorus $\left(\mathrm{P}_{2} \mathrm{O}_{5}\right)$ and potassium $\left(\mathrm{K}_{2} \mathrm{O}\right)$ was $310.30,40.27$ and $155.73 \mathrm{~kg}$ per hectare respectively.

The experiment was laid out in Randomized Block Design with four treatments with six replications. The cultivar Arka Trishna grapes with four pruning dates, i.e., $20^{\text {th }}$ January, $30^{\text {th }}$ January, $10^{\text {th }}$ February and $20^{\text {th }}$ February are details of the experiments. The vines were trained on ' $\mathrm{Y}$ ' trellis system and planting distance at $2 \mathrm{~m} \times 3 \mathrm{~m}$. All vines were kept under uniform cultural practices. Vine yield and physical characteristics of fruits were recorded when the fruits were ready for harvest. Incidence of thrips was measured by regular field observation. Mortality of renewal shoots were measured after nine months of pruning and expressed in percentage. For chemical analysis of the fruits, the methods were followed as described by A.O.A.C. (1990).

\section{Method of pruning}

The method of pruning consisted of removal of not only the past season's shoots at the level indicated but also the removal of unwanted old woods, dried, dead shoots and unthrifty growth during pruning dormant condition.

\section{Time of pruning}

The cultivar Arka Trishna grapes with four pruning dates, i.e., $20^{\text {th }}$ January, $30^{\text {th }}$ January, $10^{\text {th }}$ February and $20^{\text {th }}$ February and fruits were harvested during the month of May June.

\section{Statistical analysis}

The data were analyzed statistically and test of significance were done by following the statistical method RBD as described by Pance 
and Sukhatme (1985). The significance of the mean difference between the treatments was determined by computing the standard error and critical difference.

\section{Results and Discussion}

Yield and yield attribute characteristics of grapes

The yield attributes characters of fruits have been presented in Table 1 and 2. Yield per vine was significantly varied due to different date of pruning during period of investigation. The average yield per vine was highest when vines were pruned on $30^{\text {th }}$ January $(3.36 \mathrm{~kg})$ followed by $10^{\text {th }}$ February $(2.95 \mathrm{~kg})$ and lowest was recorded when vines were pruned on $20^{\text {th }}$ January $(1.79 \mathrm{~kg})$.

Maximum number of bunches per vine was recorded when vines were pruned on $30^{\text {th }}$ January (32.83) closely followed by $10^{\text {th }}$ February (30.67).
Highest bunch weight (102.40 g), longest bunch length $(12.5 \mathrm{~cm})$ and bunch breadth $(8.2 \mathrm{~cm})$ was recorded when vines were pruned on $30^{\text {th }}$ January. Highest yield and yield attributes characters was recorded from $30^{\text {th }}$ January pruned vines may be due to higher fruitfulness percentage of the spur and increasing size of bunches after berry set. Increasing in fruit yield with $30^{\text {th }}$ January pruning was noted by Ghosh et al., (2012) in cultivar Arka Neelamani under Jhargram condition. Chadha and Mand (1969) found that the yield was great when vines were pruned from $26^{\text {th }}$ January to $5^{\text {th }}$ February under North India condition.

The data presented in Table 3 and 4 showed that highest ten berries weight $(33.07 \mathrm{~g})$, average berry size (length $\mathrm{x}$ breadth) was recorded when vines were pruned on $10^{\text {th }}$ February. Highest juice content was measured when vines were pruned on $10^{\text {th }}$ February $(78.88 \%)$ closely followed by $20^{\text {th }}$ February (78.01\%).

Table.1 Effect of different date of pruning on yield and number of bunches of grapes cv. Arka Trishna

\begin{tabular}{|l|c|c|}
\hline Treatments & Yield per vine $(\mathrm{Kg})$ & Number of bunches per vine \\
\hline Pruning on $20^{\text {th }}$ January & 1.79 & 20.16 \\
\hline Pruning on $30^{\text {th }}$ January & 3.36 & 32.83 \\
\hline Pruning on $10^{\text {th }}$ February & 2.95 & 30.67 \\
\hline Pruning on $20^{\text {th }}$ February & 1.82 & 21.16 \\
\hline CD at 5\% & $\mathbf{0 . 5 1}$ & $\mathbf{7 . 4 0}$ \\
\hline
\end{tabular}

Table.2 Effect of different date of pruning on bunch weight, length and breadth of grapes cv. Arka Trishna

Treatments

\begin{tabular}{l} 
Pruning on $20^{\text {th }}$ January \\
\hline Pruning on $30^{\text {th }}$ January \\
\hline Pruning on $10^{\text {th }}$ February \\
\hline Pruning on $20^{\text {th }}$ February \\
\hline CD at $5 \%$
\end{tabular}

\section{Bunch weight (g) Bunch length (cm)}

10.8

12.5

10.3

10.2

0.98

\section{Bunch breadth (cm)}

\begin{tabular}{|c|c|c|}
\hline 89.21 & 10.8 & 6.2 \\
\hline 102.40 & 12.5 & 8.2 \\
\hline 96.25 & 10.3 & 6.5 \\
\hline 86.36 & 10.2 & 6.2 \\
\hline $\mathbf{6 . 9 1}$ & $\mathbf{0 . 9 8}$ & $\mathbf{1 . 0 2}$ \\
\hline
\end{tabular}


Table.3 Effect of different date of pruning on ten berries weight and average berry length of grapes cv. Arka Trishna

\begin{tabular}{|l|}
\hline Treatments \\
\hline Pruning on $20^{\text {th }}$ January \\
\hline Pruning on $30^{\text {th }}$ January \\
\hline Pruning on $10^{\text {th }}$ February \\
\hline Pruning on $20^{\text {th }}$ February \\
\hline CD at $5 \%$ \\
\hline
\end{tabular}

\begin{tabular}{|l|l|}
\hline $\mathbf{1 0}$ berries weight $(\mathrm{g})$ & A verage berry length $(\mathbf{c m})$ \\
\hline 29.18 & 2.82 \\
\hline 31.57 & 3.05 \\
\hline 33.07 & 3.17 \\
\hline 32.02 & 3.07 \\
\hline $\mathbf{2 . 0 8}$ & $\mathbf{0 . 1 7}$ \\
\hline
\end{tabular}

Table.4 Effect of different date of pruning on average berries breadth and juice content of grapes cv. Arka Trishna

\begin{tabular}{|l|l|l|}
\hline Treatments & A verage berry breadth $(\mathrm{cm})$ & Juice content (\%) \\
\hline Pruning on $20^{\text {th }}$ January & 2.82 & 76.89 \\
\hline Pruning on $30^{\text {th }}$ January & 3.05 & 76.64 \\
\hline Pruning on $10^{\text {th }}$ February & 3.17 & 78.88 \\
\hline Pruning on $20^{\text {th }}$ February & 3.07 & 78.01 \\
\hline CD at 5\% & $\mathbf{0 . 1 7}$ & $\mathbf{0 . 9 4}$ \\
\hline
\end{tabular}

Table.5 Effect of different date of pruning on mortality of shoots and incidence of thrips of grapes cv. Arka Trishna

\begin{tabular}{|l|c|c|}
\hline Treatments & $\begin{array}{c}\text { Mortality percentage of } \\
\text { renewal shoots }\end{array}$ & \begin{tabular}{c} 
Incidence of thrips \\
\hline Pruning on $20^{\text {th }}$ January
\end{tabular} \\
\hline Pruning on $30^{\text {th }}$ January & 14.20 & Negligible \\
\hline Pruning on $10^{\text {th }}$ February & 12.50 & Negligible \\
\hline Pruning on $20^{\text {th }}$ February & 11.69 & Negligible \\
\hline CD at 5\% & 11.41 & Medium \\
\hline
\end{tabular}

Table.6 Effect of different date of pruning on date of panicle emergence and harvesting period of grapes cv. Arka Trishna

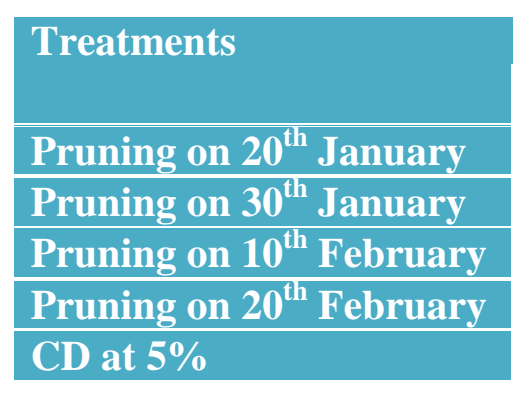

Date of panicle emergence
$8^{\text {th }}$ February
$19^{\text {th }}$ February
$28^{\text {th }}$ February
$9^{\text {th }}$ March
-


Table.7 Effect of different date of pruning on TSS, Acidity and TSS/acidity ratio of grapes cv. Arka Trishna

\begin{tabular}{|l|c|c|c|}
\hline Treatments & TSS $\left({ }^{0}\right.$ Brix $)$ & Acidity (\%) & TSS/acid ratio \\
\hline Pruning on $20^{\text {th }}$ January & 18.7 & 0.57 & 32.80 \\
\hline Pruning on $30^{\text {th }}$ January & 19.6 & 0.46 & 42.60 \\
\hline Pruning on $10^{\text {th }}$ February & 20.9 & 0.45 & 46.45 \\
\hline Pruning on $20^{\text {th }}$ February & 22.2 & 0.45 & 49.34 \\
\hline CD at 5\% & $\mathbf{1 . 1 0}$ & $\mathbf{0 . 1 4}$ & $\mathbf{8 . 6 3}$ \\
\hline
\end{tabular}

Table.8 Effect of different date of pruning on Total sugar, reducing sugar and Ascorbic acid contain of grapes cv. Arka Trishna

\begin{tabular}{|l|c|c|c|}
\hline Treatments & $\begin{array}{c}\text { Total sugar } \\
(\%)\end{array}$ & $\begin{array}{c}\text { Reducing sugar } \\
(\%)\end{array}$ & $\begin{array}{c}\text { Ascorbic acid } \\
(\mathbf{m g} / \mathbf{1 0 0} \text { ml juice) }\end{array}$ \\
\hline Pruning on $20^{\text {th }}$ January & 15.45 & 13.66 & 4.00 \\
\hline Pruning on $30^{\text {th }}$ January & 14.76 & 13.54 & 4.45 \\
\hline Pruning on $10^{\text {th }}$ February & 15.75 & 14.25 & 3.50 \\
\hline Pruning on $20^{\text {th }}$ February & 16.15 & 14.80 & 3.86 \\
\hline CD at 5\% & $\mathbf{0 . 8 7}$ & $\mathbf{0 . 9 2}$ & $\mathbf{0 . 9 4}$ \\
\hline
\end{tabular}

It was evident from the data presented in Table 5 and 6 observed that pruning on $20^{\text {th }}$ January recorded increasing mortality percentage of renewal shoots. It was further noted that delay in pruning $\left(20^{\text {th }}\right.$ February) resulted more incidence of thrips, at present is considered as serious ones. The data showed that pruning on $30^{\text {th }}$ January resulted in completion of harvesting process within the month of May i.e., before on set of rainy season while pruning on $20^{\text {th }}$ February, harvesting time extended up to $10^{\text {th }}$ June when the rainy season had already started.

\section{Quality characteristics of grapes}

The chemical composition of berries of different treatments has been presented in Table 7 and 8 . The data showed that different date of pruning exhibit significant variation with respect to total soluble solids of Arka Trishna grapes. Highest total soluble solids content of the berry was measured when vines were pruned on $20^{\text {th }}$ February $\left(22.2^{0}\right.$ brix $)$ and lowest when vines were pruned on $30^{\text {th }}$ January $\left(18.7^{0}\right.$ brix $)$. This kind of similar phenomena was reported by earlier worker Ghosh et al., (2012) reported that highest TSS content in the berries when vines were pruned on $20^{\text {th }}$ January in Arka Neelamani cultivar under Jhargram condition. The highest acidity percentage $(0.57 \%)$ of berry was measured when vines were pruned on $20^{\text {th }}$ January and lowest when vines were pruned on $10^{\text {th }}$ February and $20^{\text {th }}$ February $(0.45 \%)$.

Most important quality character TSS/acid ratio was highest when vines were pruned on $20^{\text {th }}$ February (49.34). The total sugar (16.15 $\%)$ and reducing sugar $(14.80 \%)$ content was highest when vines were pruned on $20^{\text {th }}$ February. Increasing TSS content and decreasing acid content of berry under this date of pruning may be due to favorable temperature and relative humidity during fruit maturity period. Ascorbic acid content was recorded highest when vines were pruned on $30^{\text {th }}$ January ( $4.45 \mathrm{mg} / 100 \mathrm{ml}$ juice). 
Considering the above study in view it can be concluded that proper time of pruning is very essential for improving production of grapes under this climatic condition. On the basis of present findings, it can be concluded that $30^{\text {th }}$ January appeared to be the appropriate time for pruning the vines under Bankura conditions with regard to yield attributes and quality.

\section{References}

A.O.A.C. 1990. Official method of analysis. Association of analytical chemists. $15^{\text {th }}$ edn. Washington, D.C.

Chadha, K, L, 2008. Indian viticulture scenario. Acta Horticulture. 785: 59-68.

Chadha, K.L., and Shikhamany, S.D. 1999. The Grapes. Improvement, Production and Post-Harvest Management. Malhotra Publishing Hose, New Delhi.
Chadha, K.L., Mand, A.S. 1969. Effect of time and severity of pruning on maturity, yield and quality of Anab-eShahi grape. Journal of Research. Punjab Agricultural University. 6: 80820.

Ghosh, S.N., Bera, B, Roy, S and Kundu, A. 2012. Adaptation and commercialization of viticulture in West Bengal - a new area in India. Acta Horticulture. 931: 389-399.

Panse, V.G., and Sukhatme, P.V. 1985. Design of Experiments. VIII Randomized Blocks and Latin Square. In: Statistical methodology for Agricultural workers. Indian Council of Agricultural Research, New Delhi.

Radha, T., and Mathew, L. 2007. Fruit Crops: Sub-Tropical Fruits. New India Publushing Agency. Pritam Pura, New Delhi.

\section{How to cite this article:}

Ranjit Pal and Ghosh, S.N. 2018. Effect of Time of Pruning on Fruit Production and Berry Quality of Grapes (Vitis vinifera) under Bankura Condition of West Bengal. Int.J.Curr.Microbiol.App.Sci. 7(10): 1994-1999. doi: https://doi.org/10.20546/ijcmas.2018.710.230 